\title{
Prolactin-mediated gene activation in mammary epithelial cells
}

\author{
Bernd Groner and Fabrice Gouilleux
}

\author{
Tumor Biology Center, Freiburg, Germany
}

\begin{abstract}
Mammary epithelial cells grow and develop with the onset of sexual maturity. In addition, lobular alveolar structures are formed during pregnancy, and quiescent differentiated cells secrete high levels of milk proteins after parturition. These events are governed by multiple hormones and growth factors and involve the sequential and synergistic action of functionally distinct signal transduction pathways. Milk protein genes have been analyzed and composite response elements have been identified in the promoter sequences. Transcription factors, which relay the hormonal signals, bind to these sequences. The factor that confers prolactin stimulation to milk protein gene transcription has recently been identified. MGF/Stat 5 is a latent transcription factor that becomes activated by a tyrosine-specific protein kinase, Jak2, associated with the prolactin receptor. Tyrosine phosphorylation converts the latent factor into one with DNA-binding and transcriptional activation potential. The regulation of MGF/Stat5 in vitro and in vivo indicates that it is a central component of the lactogenic hormone signaling pathway. Involvement of MGF/Stat5 in the signaling by other cytokines indicates that the same factor might be involved in regulation of growth-promoting genes, primarily in hematopoietic cells.
\end{abstract}

Current Opinion in Genetics \& Development 1995, 5:587-594

\section{Introduction}

The post-natal development of the mammary gland and mammary epithelial cells has been extensively studied. The morphogenesis of the gland has been described and the signals governing differentiation and organ-specific gene expression have been identified. Cell contacts in the mammary gland [1] and basement membrane interactions [2-5] are important for the establishment of the differentiated phenotype. Lastly, cell hormone interactions are responsible for the induction of milk protein gene transcription [6-8]. The multitude of regulatory components and signals has complicated the molecular biological analysis of gene regulation in mammary epithelial cells. Some signals have been found to act in a sequential fashion, others act synergistically or antagonistically. Only the development of in vitro cell culture systems has allowed the defined manipulation of single variables and their correlation with particular phenotypic effects. This has led to a molecular biological approach to the study of lactogenic hormone action and the characterization and cloning of central components. Insights gaincd in the in vitro cultured cells have been verified in vivo.

In this review, we describe the steps leading to the discovery of MGF/Stat5. This factor confers the transcriptional regulation by prolactin to the milk protein genes in mammary epithelial cells. MGF/Stat 5 has been identified as a member of a transcription factor family, signal transducers and activators of transcription (Stat), that mediates the action of many different cytokines.

\section{Hormonally responsive mammary epithelial cell lines}

In the cell clone HC11, isolated from mouse mammary epithelial cells, it has been shown that the endogenous $\beta$-casein milk protein gene is rapidly induced by the lactogenic hormones without any requirements for extracellular matrix components or co-cultivation with other cell types $[9,10]$. This cell line has greatly facilitated the investigation into the molecular mechanisms of lactogenic hormone action and allowed the identification of regulatory DNA sequences in the promoter regions of the milk protein genes and specific nuclear interacting factors.

Transfections of $\mathrm{HC} 11$ cells with rat $\mathrm{B}$-casein promoter-reporter gene constructs led to the delimitation of promoter sequences responsive towards lactogenic hormones [11]. It was found that prolactin and gluco- 
corticoid hormones synergistically induce expression of a transfected $\beta$-casein promoter construct when the cells are kept in the presence of insulin. All three lactogenic hormones (insulin, glucocorticoids, and prolactin) are required for transcriptional induction of the $\beta$-casein gene promoter, but a short segment of the promoter is sufficient to confer the response. Kinetic experiments indicated that prolactin and glucocorticoids control transcription by distinct mechanisms [12]. Dexamethasone increases the sensitivity of the cells to respond to prolactin. This increase in sensitivity is slow and can be rapidly reversed by withdrawal of dexamethasone.

In subsequent studies, it was shown that an interdependence exists between the signaling pathways. Lactogenic hormone action was investigated during the simultaneous activation of growth factor receptors. It was found that activation of epidernal growth factor receptor, but not of the ErbB-2 receptor, prevents lactogenic hormone induction in HC11 cells [13]. Stimulation of $\mathrm{HC} 11$ cells with $\mathrm{Neu}$ differentiation factor/heregulin induces phosphorylation of ErbB-2 and ErbB-3 and stimulates HC11 cell proliferation. Like epidermal growth factor (EGF), heregulin inhibits the lactogenic hormone induced expression of $\beta$-casein at the level of transcription [14]. Growth-promoting effects of EGF and the differentiation-specific signaling of the lactogenic hormones appeared to be mutually exclusive. However, the lactogenic hormone response was not counteracted by all proliferative signals. Activation of c- $m y c$ gene expression in mammary epithelial cells did not interfere with $\beta$-casein gene transcription $[15,16]$.

Complementary to the study of milk protein genes in cultured cells, transgenic mice have been used to elucidate regulatory sequences in these gene promoters and the function of specific transcription factors. The rat $\beta$ casein gene promoter [17] and the whey acidic protein (WAP) gene promoter have been extensively investigated [18-21].

\section{Transcription factors involved in lactogenic hormone action}

The multitude of signals regulating the individual milk protein genes and the composite response elements found in their promoter sequences make it likely that a number of different transcription factors are involved in their transcriptional regulation. The delimitation of promoter sequences relevant for the lactogenic hormone induction in transfected cultured cells and in transgenic mice has provided the information necessary for factor identification. Insulin, glucocorticoids, and prolactin are required for the induction of two of the major milk protein genes, the $\beta$-casein and WAP genes. Glucocorticoids exert their transcriptional effect via the glucocorticoid reccptor, a ligand-dependent transcription factor. Glucocorticoid receptor binding sites have been found in the promoter regions conferring the lactogenic hormone response [22]. Sequence motifs that represent half-sites of the classic glucocorticoid receptor binding sites have been identified and interpreted as delayed secondary glucocorticoid-tesponse elements. Cooperation between glucocorticoid receptor and other transcription factors is likely. Glucocorticoid regulation of the WAP gene promoter seems to involve indirect effects. Alterations in the chromatin structure of the distal promoter region are effected by glucocorticoids [23].

A region in the $\beta$-casein gene promoter has been identified that confers negative regulation. This repression of transcription in the uninduced state is mediated by a promoter element located at position -110 to -150 and comprises two interacting protein-binding sites. One of the nuclear factors interacting with the proximal site within the repressor region has been identified as the nuclear factor $\mathrm{YY}-1\left[24^{\bullet}\right]$. Mutations in this regulatory region result in an increase in constitutive transcription. The YY-1-binding site is located in close proximity to that for the prolactin-regulated factor MGF/Stat5. Both proteins seem to compete for binding to overlapping sequences $\left[24^{\bullet}, 25\right]$.

Regions have been identified in the WAP promoter that contribute to tissue-specific and stage-specific expression. A region between -120 and -100 is important for hormone -independent promoter function. Analysis of specific binding proteins has revealed that members of the Ets family of DNA-binding proteins recognize this site [26]. Analysis of this factor-binding site in transgenic mice revealed that the Ets-binding site plays a critical role in the activation of WAP promoter transgenes during pregnancy, but is not required for high expression during the lactation period. Ets proteins might function as stage-specific transcriptional activators in the developing mammary gland [27].

A pregnancy-specific mammary nuclear factor has been found to bind to two regions in the mouse $\beta$-casein gene promoter. This factor is regulated by progesterone and is involved in the repression of gene transcription during pregnancy. Progesterone suppresses hormone induction by the lactogenic homones prolactin, hydrocortisone, and insulin [28].

Additional DNA sequence elements in the promoter of the $\beta$-casein gene have been identified. A negative regulatory element in the region between -221 and -183 and a positive regulatory element between -183 and -170 have been found. The promoter element between -194 and -163 binds to sequence-specific single-stranded DNA-binding proteins that exclusively recognize the upper DNA strand. They play a role in the repression of transcription. The DNA-binding activity of these nuclear proteins is hormonally controlled. Their repressive function is active in late pregnancy and post-lactation, but not during lactation. They might be sequestered by a single-stranded nucleic acid protein binding site in the $\beta$-casein mRNA during the lactation period $\left[29,30^{\bullet}\right]$.

NF-1 has been identified as a major factor regulating the transcription of the WAP gene. It binds to a 
DNase I hypersensitive site between positions -800 and -700 in the promoter region. This site is critical for the transcriptional activation of the mouse WAP and the sheep $\beta$-lactoglobulin genes [31॰]. Additional specific nucleic binding sites in the mouse $\beta$-casein gene promoter have been found by DNase I footprinting analysis and band-shift assays [32]. A summary of the nuclear factor binding sites identified in the proximal essential region of the $\beta$-casein gene promoter is shown in Fig. 1.

\section{Prolactin action and inducible genes}

The simultaneous activation of multiple receptors during lactogenic hormone action made it difficult to correlate individual transcription factors with individual hormonal signals. The development of a cell culture system in which individual signals could be manipulated and others held constant allowed researchers to focus on prolactin signal transduction. The WAP gene promoter $[33,34]$, the anx Icp35 gene promoter [35], the as1-casein gene promoter [36], and the $\beta$-lactoglobulin gene promoter [37] allowed comparisons with the $\beta$-casein gene promoter and facilitated the search for DNA elements conferring prolactin regulation. As prolactin action is not restricted to mammary epithelial cells, promotor elements in other cell types have been found to be valuable. The prolactin-dependent rat $T$-lymphoma $\mathrm{Nb} 2$ cells express genes (clone 15 and interferon regulatory factor $1[38,39]$ ) that allow conclusions to be drawn about promoter sequences conferring the prolactin response.
Another reason to focus on the prolactin aspect of lactogenic hormone regulation was the rapid progress made in the study of the prolactin receptor. Cloning of the gene and the structural analysis of the prolactin receptor contributed important insights [40]. The prolactin receptor belongs to the cytokine growth hormone/prolactin receptor superfamily. These receptors associate with cytoplasmic tyrosine kinases of the Jak family. Prolactin receptor activation results in the tyrosine phosphorylation of the kinase, the receptor, and cellular substrates that confer the transcriptionial response [41•].

\section{Discovery, purification and molecular cloning of MGF/Stat5}

A strongly conserved sequence element is present in the region between -80 and -100 of casein genes from different species. Using DNase I footprinting analysis, methylation-interference assays, and band-shift analysis, a specific nuclear factor interacting with this sequence was found. This factor recognizes the DNA sequence 5'-ACTTCTTGGAATT-3'. It is present in the mammary gland tissue of lactating animals [42] and is termed mammary gland factor (MGF). Three binding sites for MGF have also been found in the $\beta$-lactoglobulin gene promoter [43] and the sequence is conserved in the $\alpha$-casein and $\beta$-casein gene promoters of cows and rodents at position -87 to -99 . Bovine and rodent MGF have identical DNA-binding properties and form protein-DNA complexes with the same electrophoretic migration properties. MGF has been

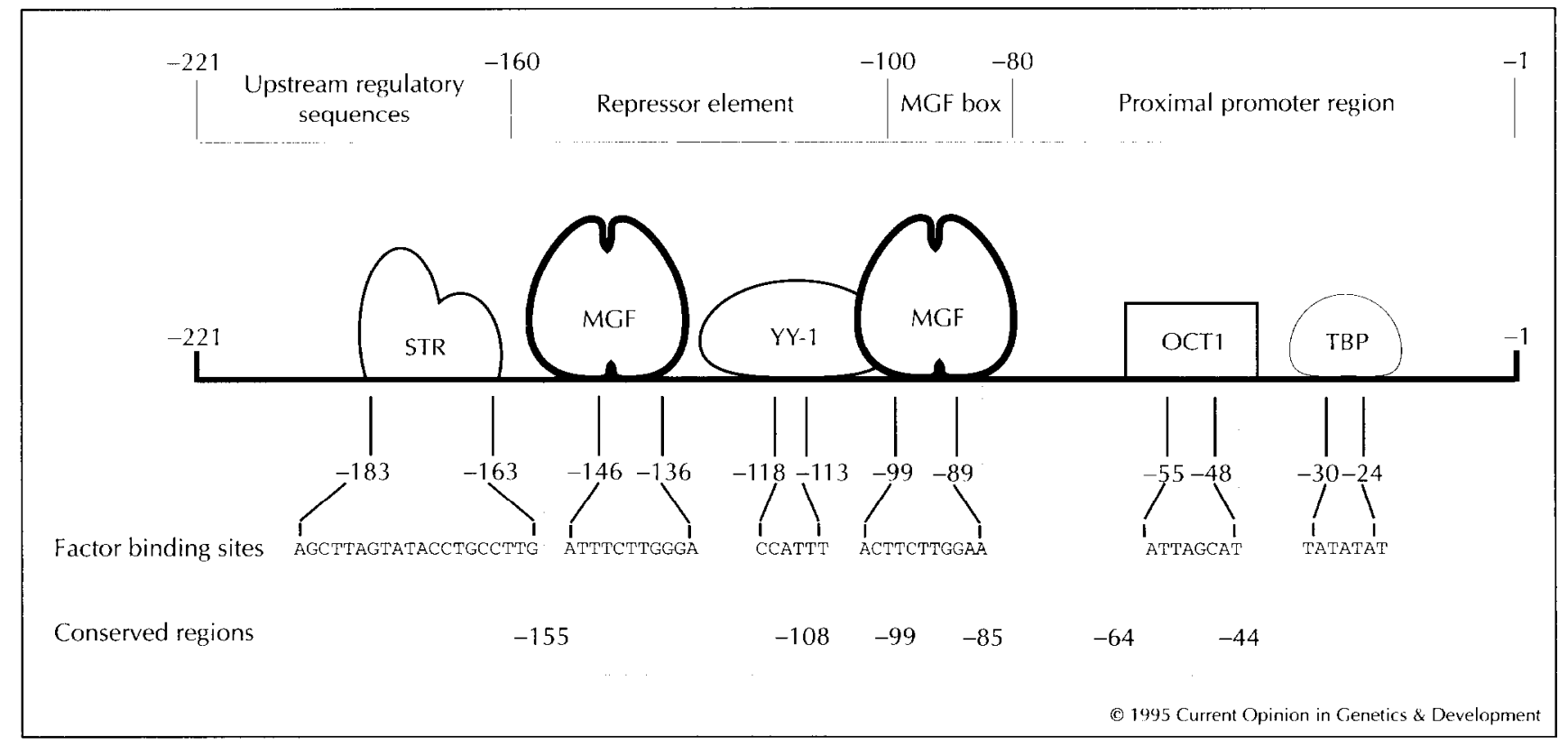

Fig. 1. Nuclear factor binding sites in the B-casein gene promoter. The binding sites for nuclear factors are indicated in the lower part of the picture. The sequence-specific single-stranded DNA-binding factor (STR) recognizes the upper strand of the region between -163 and -183 and has a repressing role on transcription in the absence of hormones. Two binding sites for MCF/Stat5 have been identified. A low-affinity site is present between positions -136 and -146 and a high-affinity site between positions -89 and -99 . The recognition sequences for the YY-1 factor are present between positions -113 and -118 . The region between -100 and -160 also exerts repressing functions. Downstream of the high-affinity MGF-binding site, an OCT1-binding site and a proximal promoter region have been identified. TBP, TATA-binding protein. 
purified from nuclear extracts of mammary epithelial cells from lactating rats [44] and lactating sheep [45*0] by sequence-specific DNA-affinity chromatography. Proteins of $84 \mathrm{kDa}$ and $92 \mathrm{kDa}$ were obtained, partial amino acids sequences were determined, and a cDNA clone of MGF was isolated. MGF comprises 794 amino acids and has sequence homology with members of the Stat family of transcription factors. It is encoded by mRNAs of $6.5 \mathrm{~kb}$ and $4.5 \mathrm{~kb}$. mRNA expression was found in mammary tissue, ovaries, thymus, spleen, kidney, lung, muscle, and adrenal gland. Homologs of sheep MGF/Stat5 have been cloned from human cells [46] and two isoforms of mouse Stat 5 with $96 \%$ sequence identity have been characterized $\left[47,48^{\bullet}\right]$.

\section{Regulation of MGF/Stat5 activity in cultured cells}

The mechanism of prolactin activation of MGF/Stat5 has been studied in COS cells co-transfected with cDNA encoding Stat 5 and the prolactin receptor. Prolactin treatment of the transfected cells caused activation of Stat5 within minutes. This activation is independent of ongoing protein synthesis. Tyrosine kinase inhibitors prevented Stat5 activation and treatment of activated Stat5 with tyrosine-specific protein phosphatases abolished its DNA-binding activity. The prolactin response of the $\beta$-casein milk protein gene promoter was observed in cells co-transfected with a $\beta$-casein promoter reporter construct. Substitution of the tyrosine at position 694 in MGF/Stat5 by a phenylalanine residue prevented phosphorylation upon prolactin induction and transcriptional transactivation [490*]. MGF/Stat5 was also able to enhance the in vitro transcription from a $\beta$-casein gene promoter [50]. These experiments formally established MGF/Stat5 as the mediator of prolactin-induced gene transcription. Prolactin was also able to induce MGF/Stat5 in HC11 cells [51]. In these cells, however, the synergistic action of glucocorticoids, insulin, and prolactin is necessary for the induction of the $\beta$-casein gene promoter. The fact that prolactin efficiently activates the promoter in transfected COS cells might be a result of the high expression of MGF/Stat5 in the transiently transfected cells. A very strong MGF/Stat 5 signal may make the cooperating signals superfluous. Induction of MGF/Stat5 by prolactin and experimental evidence for its phosphorylation in confluent cultures of mammary epithelial cells was also obtained by Welte et al. [52].

Cross-talk between signal transduction pathways is observed when lactogenic hormone induced signal transduction is related to the action of protein kinase C. Downregulation of protcin kinasc $\mathrm{C}$ inhibits $\beta$-cascin protein expression induced by the lactogenic hormones in $\mathrm{HC} 11$ cells. This inhibition occurs at the level of transcription and coincides with an inhibition of $\mathrm{MGF} / \mathrm{Stat} 5$ activation [53]. A similar observation was made when the influence of EGF and signals downstream of the EGF receptor on the lactogenic hormone response were studied. EGF, activated $\mathrm{Ha}-\mathrm{Ras}$, or activated $\mathrm{v}-\mathrm{R}$ af block the lactogenic induction of MGF/Stat5 and $\beta$-casein gene transcription [54].

\section{Regulation of MGF/Stat5 activity in the mammary gland during pregnancy and lactation}

The important role that MGF/Stat5 plays in the conferral of the prolactin response has been corroborated through observations in animal tissues. Using band-shift analysis, it was found that nuclear extracts from mammary glands of mice taken towards the end of pregnancy and during the lactation period exhibit high MGF/Stat5 activity. Withdrawal of suckling pups from their mothers during the lactation period causes a strong and rapid decrease of MGF/Stat5 DNA-binding activity. Restoration of the pups to their mothers increases MGF/Stat5 DNA binding to maximum levels within four hours [55]. In the lactating animals, MGF/Stat5 activity is regulated by suckling, milk stasis, and systemic hormone signals. In addition to the systemic signals, signals originating in the mammary gland cooperate in the in vivo regulation of MGF/Stat5 activity [56].

A comparison of the isoforms of Stat5 (Stat5a and Stat5b) has been carried out. Similar levels of Stat5a and Stat5b mRNA were found in most tissues of virgin and lactating mice. Both Stat5a and Stat5b mediate prolactin-induced transcription upon transfection into COS cells. An increase in Stat5 expression is observed during pregnancy and coincides with the activation of milk protein gene transcription [48*]. The two genes encoding Stat5a and Stat5b have also been studied in rat mammary gland [57]. The levels of Stat5a mRNA and protein were measured during pregnancy and were found to be highest in late pregnancy. They slightly decreased during lactation and did not correlate quantitatively with milk protein expression.

\section{MGF/Stat5 is activated by numerous cytokines and growth factors}

It was initially assumed that the regulation of milk protein genes in mammary epithelial cells would be affected by a tissue-specific transcription factor. Prolactin is active in many organs, though, so it was not surprising to find MGF/Stat5-like activity in different prolactin-responsive cells, such as Nb2 T-lymphoma cells. However, it was surprising to find that MGF/Stat5 activation is not restricted to the prolactin receptor signaling. Co-transfection of MGF/Stat5 cDNA and growth hormone receptor CDNA into COS cells showed that growth hormone treatment of the transfected cells results in MGF/Stat5 activation [58]. In addition to prolactin and growth hormone, erythropoietin and granulocyte/macrophage colony stimulating factor were also shown to be able to induce MGF/Stat5 [59]. The intracellular domain of the erythropoietin receptor crucial for MGF/Stat5 activation has recently been identified [60]. 
These results suggest that MGF/Stat5 not only regulates physiological processes in mammary epithelial cells, but also plays an important role in hematopoietic cells. This hypothesis gained credence when the connections between MGF/Stat5 and additional cytokines were discovered. Stat 5 can also be activated by interleukin (IL) 2. The cytoplasmic region of the IL-2 receptor $\beta c$-chain is required for this activation [61]. These experiments also showed that Stat 5 activation is not restricted to receptors activating Jak2, but can also be affected by Jak3. IL-2-mediated activation of Stat 5 has also been observed in the transformed human lymphocyte cell line [46], a cytotoxic T-cell line CTLL-2 [62], and Nb-2 lymphoma cells [63].

IL-3, like IL-2, is an important regulator of hematopoietic cells and exerts its effects partially on the activation of specific transcription factors. Characterization of the IL-3-induced factor shows that a mouse homo$\log$ of MGF/Stat5 can be activated in response to IL-3 $[47,64,65]$. Further inducers of MGF/Stat 5 were found when a differentiation-induced factor (DIF) in myeloid cells was investigated [66]. The treatment of myeloid cells with colony-stimulating factor 1 , granulocyte/macrophage colony stimulating factor or interferon- $\gamma$ results in the induction of DIF. The DIF complexes are partially made up of MGF/Stat5 or closely related proteins.

Thrombopoietin is a cytokine that regulates the levels of circulating platelets and controls proliferation and differentiation of megakaryocytes. It acts via the thrombopoietin receptor, c-Mpl. Activation of $\mathrm{c}-\mathrm{Mpl}$ by thrombopoietin or constitutive activation of a transforming viral variant, $\mathrm{v}-\mathrm{Mpl}$, in COS cells or UT7 cells resulted in MGF/Stat5 activation [67]. Finally, the signal transduction pathway through Stat 5 seems to extend to growth factors that bind to tyrosine kinase receptors. Intraperitoneal treatment of mice with EGF [68] or heregulin (M Jeschke, B Groner, unpublished data) causes the activation of MGF/Stat5 in liver cells.

\section{The prolactin response factor MGF/Stat5 plays a role in differentiation-specific gene expression and growth control}

The Jak/Stat pathway has now been well established as one arm of cytokine-mediated signal transduction $\left[69^{\bullet}, 70^{\bullet}\right]$. Cytokine receptor stimulation results in the recruitment and activation of non-receptor protein tyrosine kinases that trigger their signaling cascade. Tyrosine phosphorylation of the kinase itself, the intracellular domain of the receptors, and cellular substrates are observed. The intracytoplasmic region of the cytokine receptors seems to be able to recruit different cellular substrates and ultimately determine the specificity of the signaling events. A scheme for the prolactin-induced activation of MGF/Stat5 is shown in Fig. 2.

It seems as though MGF/Stat5-Inediated transcriptional induction couples to differentiation-specific gene transcription events in mammary epithelial cells and proliferation signals in hematopoietic cells. Suggestive evidence indicates that the inappropriate activation of Jak kinases and Stat proteins could also be involved in malignant transformation. A dominant mutation of the Drosophila homolog of the Jak kinase causes developmental defects [71] and hematopoietic neoplasias [72]. Elevated levels of Stat DNA-binding activity have been found in breast carcinomas [73०], oncogene-induced nlouse mammary carcinomas [54], and v-Mpl-transformed hematopoietic cells [67]. It is

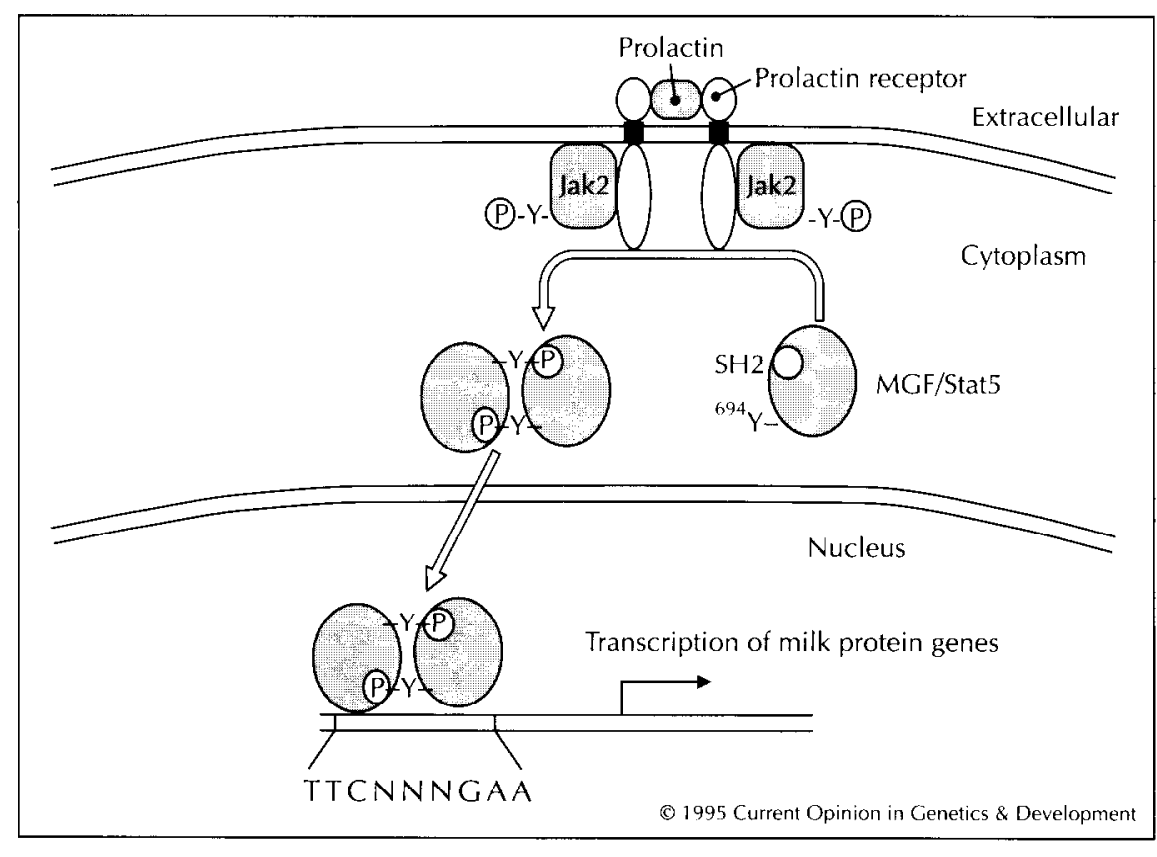

Fig. 2. MGF/Statל is a signal transducer and transcriptional activator. Upon binding of prolactin to the extracellular domain of the prolactin receptor, dimerization of the receptor takes place. Jak2 is associated with the intracellular domain of the prolactin receptor. This tyrosinespecific protein kinase becomes activated upon prolactin receptor dimerization. MGF/Stat5 is present as a latent factor in the cytoplasm and is a substrate of the Jak2 kinase. Upon phosphorylation at tyrosine residue $(Y)$ 694, MGF/Stat5 dimerizes and assumes DNA-binding properties. The dimer of MGF/Stat5 binds to sequence elements present in target genes that have the consensus sequence 5'-TTCNNNGAA-3' (where N can be any nucleotide). 
conceivable that the activation of MGF/Stat 5 is a normal proliferative signal in hematopoietic cells and a signal for differentiation-specific gene expression in mammary epithelial cells. Inappropriate activation of MGF/Stat 5 in mammary cells at a differentiation stage before they have reached quiescence might confer a proliferative stimulus and thus contribute to their transformation.

\section{Conclusions}

The study of hormonally regulated gene expression in highly differentiated mammary epithelial cells led to the discovery and cloning of the transcription factor MGF/Stat5. This transcription factor is activated by prolactin, one of the lactogenic hormones. The regulation of its activity through tyrosine phosphorylation is an unusual feature for a transcription factor and defines it as a member of the Stat family. Its prominent induction during the lactation period initially led to the suggestion that it was a mammary-specific factor. The investigation of its mRNA expression pattern then showed that the gene is transcribed in most tissues. It was also found that the activation of MGF/Stat 5 is not restricted to prolactin, but that a large number of cytokines (e.g. IL-2, IL-3, IL-5, granulocyte/macrophage colony stimulating factor, erythropoietin, thrombopoietin, and growth hormone) use MGF/Stat 5 as a signaling intermediate. It is likely, therefore, that MGF/Stat5 plays a role in the transcription of differentiation-specific genes as well as growth-promoting genes. The cell type specific expression of individual cytokine receptors, the positively or negatively regulating properties of Stat5 isoforms and splice variants, and the composite nature of the promoter regions of the responsive genes will have to be considered as factors that determine the function of Stat 5 in different cell types.

\section{References and recommended reading}

Papers of particular interest, published within the annual period of review, have been highlighted as:

- of special interest

-. of outstanding interest

1. Pitelka DR, Hamamoto ST, Duafala JG, Nemanic MK: Cell contacts in the mouse mammary gland. / Cell Biol 1973 $56: 797-818$

2. Schmidhauser C, Bissell MJ, Myers CA, Casperson CF Extracellular matrix and hormones transcriptionally regulate bovine beta-casein $5^{\prime}$ sequences in stably transfected mouse mammary cells. Proc Natl Acad Sci USA 1990, 87:9118-9122.

3. Zeigler ME, Wicha MS: Posttranscriptional regulation of alphacasein-mRNA accumulation by laminin. Exp Cell Res 1992, 200.481-489.

4. Sympson CJ, Talhouk RS, Alexander CM, Chin JR, Clift SM, Bissell M], Werb $Z$ : Targeted expression of stromelysin-1 in mammary gland provides evidence for a role of proteinases in branching morphogenesis and the requirement for an intact basement membrane for tissue specific gene expression. / Cell Biol 1994, 125:681-693.

5. Streuti $\mathrm{CH}$, Schmidhauser C, Bailey N, Yurchenco P, Skubitz $A$, Roskelley $C$, Bissell M]: Laminin mediates tissue specific gene expression in mammary epithelia. / Cell Biol 1995, 129:591-603.
6. Topper YI, Freeman CS: Multiple hormone interactions in the developmental biology of the mammary gland. Physiol Rev 1980, 60:1049-1056.

7. Hobbs AA, Richards DA, Kessler DI, Rosen IM: Complex hormonal regulation of casein gene expression. I Biol Chem $1982,257: 3598-3605$.

8. Groner B, Altiok S, Meier V: Hormonal regulation of transcription factor activity in mammary epithelial cells. MOl Cell Endocrinol 1994, 100:109-114.

9. Danielson KG, Oborn Cl, Durban EM, Butel IS, Medina D: Epithelial mouse mammary cell line exhibiting normal morphogenesis in vivo and functional differentiation in vitro. Proc Natl Acad Sci USA 1984, 81:3756-3760.

10. Ball RK, Friis RR, Schoenenberger CA, Doppler W, Groner $B$ : Prolactin regulation of beta-casein gene expression and of a cytosolic 120-kd protein in a cloned mouse mammary epithelial cell line. $E M B O$ ) 1988, 7:2089-2095.

11. Doppler W, Groner B, Ball RK: Prolactin and glucocorticoid hormones synergistically induce expression of transfected rat beta-casein gene promoter constructs in a mammary epithelial cell line. Proc Natl Acad Sci USA 1989, 86:104-108.

12. Doppler W, Hock W, Hofer P, Groner B, Ball RK: Prolactin and glucocorticoid hormones control transcription of the betacasein gene by kinetically distinct mechanisms. Mol Endocrinol $1990, \mathbf{4}: 912-919$.

13. Hynes NE, Taverna D, Harwerth IM, Ciardiello F, Salomon D, Yamamoto T, Groner B. Epidermal growth factor, but not erbB2 , activation prevents lactogenic hormone induction of the beta-casein gene in mouse mammary epithelial cells. Mol Cell Biol 1990, 10:4027-4043.

14. Marte BM, leschke $M$, Graus-Porta D, Taverna D, Groner $B$, Yarden $Y$, Hynes NE: Neu differentiation factor/heregulin modulates growth and differentiation of $\mathrm{HC11}$ mammary epithelial cells. Mol Endocrinol 1995, 9:14-23.

15. Ball RK, Ziemiecki A, Schönenberger CA, Reichmann E, Redmond $S$, Groner $B$ : v-Myc alters the response of a cloned mouse mammary epithelial cell line to lactogenic hormones. Mol Endocrinol 1988, 2:133-142.

16. Schönenberger $C A$, Andres $A C$, Groner $B$, Van der Valk $M$, LeMeur $M$. Gerlinger $P$ : Targeted $c$-myc gene expression in mammary glands of transgenic mice induces mammary tumors with constitutive milk protein gene transcription. $E M B O$ / 1988, 7:169-175.

17. Lee KF, Atiee SH, Rosen IM: Differential regulation of rat betacasein chloramphenicol acetyltransferase gene expression in transgenic mice. Mol Cell Biol 1989, 9:560-565.

18. Burdon T, Sankaran L, Wall RJ, I lennighausen L: Expression of a whey acidic protein transgene during mammary development: evidence for different mechanisms of regulation during pregnancy and lactation. / Biol Chem 1991, 266:6909-6914.

19. Mcknight RA, Shamay A, Sankaran L, Wall RJ, Hennighausen $L$ : Matrix attachment regions impart position independent regulation of a tissue specific gene in transgenic mice. Proc Natl Acad Sci USA 1992, 89:6943-6947.

20. Li S, Rosen JM: Distal regulatory elements required for rat whey acidic protein gene expression in transgenic mice. / Biol Chem 1994, 269:14235-14243.

21. Devinoy E, Thepot D, Stinnakre MG, Fontaine ML, Grabowski $H$, Puissant C, Pavirani A, Houdebine LM: High level production of human growth hormone in the milk of transgenic mice: the upstream region of the rabbit whey acidic protein (WAP) gene targets transgene expression to the mammary gland. Transgenic Res 1994, 3:79-89.

22. Welte T, Philipp S, Cairns C, Gustafsson JA, Doppler W Glucocorticoid receptor binding sites in the promoter region of milk protein genes. I Steroid Biochem Mol Biol 1993 47:75-81.

23. Li S, Rosen JM: Glucocorticoid regulation of rat whey acidic protein gene expression involves hormone induced alterations 
of chromatin structure in the distal promoter region. $\mathrm{Mol}$ Endocrinol 1994, 8:1328-1335.

24. Meier VS, Groner B: The nuclear factor YY1 participates in repression of the beta-casein gene promoter in mammary epithelial cells and is counteracted by mammary gland factor during lactogenic hormone induction. Mol Cell Biol 1994, 14:128-137.

This paper shows that not only positive regulation, but also the relief of repression, is part of the lactogenic hormone induction of transcription. $Y Y-1$ is a transcription factor that participates in the repression process.

25. Raught B, Khursheed B, Kazansky A, Rosen I: YY-1 represses beta-casein gene expression by preventing the formation of a lactation associated complex. Mol Cell Biol 1994, 14:1752-1763.

26. Welte T, Garimorth K, Philipp S, Jennewein P, Huck C, Cato AC, Doppler W: Involvement of Ets-related proteins in hormone-independent mammary cell-specific gene expression. Eur J Biochem 1994, 223:997-1006.

27. Mcknight RA, Spencer M, Dittmer J, Brady JN, Wall RJ Hennighausen $L$ : An ets site in the whey acidic protein gene promoter mediates transcriptional activation in the mammary gland of pregnant mice but is dispensible during lactation. Mol Endocrinol 1995, 9:in press.

28. Lee $C S$, Oka $T$ : A pregnancy-specific mammary nuclear factor involved in the repression of the mouse beta-casein gene transcription by progesterone. I Biol Chem 1992, 267:5797-5801.

29. Altiok S, Groner B: Interaction of two sequence-specific single-stranded DNA-binding proteins with an essential region of the beta-casein gene promoter is regulated by lactogenic hormones. Mol Cell Biol 1993, 13:7303-7310.

30. Altiok S, Groner B: Beta-casein mRNA sequesters a - $\quad$ single-stranded nucleic acid-binding protein which negatively regulates the beta-casein gene promoter. Mol Cell Biol 1994, 14:6004-6012.

MGF/Stat5 is not the only transcription factor that participates in B-casein gene transcription and is lactogenic hormone regulated. The single-stranded DNA-binding proteins (STR) show an inverse regulation to MGF/Stat5. They are present in the nucleus in the absence of hormone and exert a repressive function, relieved after hormone addition.

31. Li S, Rosen IM: Nuclear factor I and mammary gland factor - (STAT5) play a critical role in regulating rat whey acidic protein gene expression in transgenic mice. Mol Cell Biol 1995, 15:2063-2070.

This paper describes the use of transgenic mouse lines to investigate the consequences of mutations in nuclear factor binding sites on the tissue specificity and hormonal inducibility of milk protein promoters. Transgene expression was totally lost when the nuclear factor I binding site in the tissue-specific nuclease hypersensitive region was mutated. A drastic reduction in gene expression, but no alteration of tissue specificity, was observed when an adjacent Stat 5 binding site was mutated.

32. Kanai A, Nonomura $N$, Yoshimura $M$, Oka T: DNA-binding proteins and their cis-acting sites controlling hormonal induction of a mouse beta-casein::CAT fusion protein in mammary epithelial cells. Gene 1993, 126:195-201

33. Doppler $W$, Villunger A, Jennewein $P$, Brduscha $K$, Groner $B$, Ball R: Lactogenic hormone and cell type specific control of the whey acidic protein gene promoter in transfected mouse cells. Mol Endocrinol 1991, 5:1624-1632.

34. Devinoy E, Malienou-N'Gassa R, Thepot D, Puissant C, Houdebine LM: Hormone responsive elements within the upstream sequences of the rabbit whey acidic protein (WAP) gene direct chloramphenicol acetyl transferase (CAT) reporter gene expression in transfected rabbit mammary cells. $\mathrm{Mol} \mathrm{Cell}$ Endocrinol 1991, 81:185-193.

35. Sidis $Y$, Horseman ND: Prolactin induces rapid p95/p70 tyrosine phosphorylation, and protein binding to GAS-like sites in the anx Icp35 and c-fos genes. Endocrinol 1994, 134:1979-1985.

36. Pierre S, Jolivet G, Devinoy E, Houdebine LM: A combination of distal and proximal regions is required for efficient prolactin regulation of transfected rabbit alpha s1-casein chloramphenicol acetyltransferase constructs. Mol Endocrinol 1994, 8:1720-1730.

37. Whitelaw CB: Regulation of ovine beta-lactoglobulin gene expression during the first stage of lactogenesis. Biochem Biophys Res Comm 1995, 209:1089-1093.

38. Axtell SM, Truong TM, O'Neal KD, Yu-Lee L: Characterisation of a prolactin inducible gene, clone 15 , in $\mathrm{T}$ cells. Mol Endocrinol 1995, 9:312-318.

39. Stevens AM, Wang Y, Sieger KA, Lu H, Yu-Lee L: Biphasic transcriptional regulation of the interferon regulatory factor-1 gene by prolactin: involvement of gamma-interferon activated sequence and Stat related proteins. Mol Endocrinol 1995, 9:513-525.

40. Kelly PA, Diiane J, Postel-Vinay MC, Edery M: The prolactin/growth hormone receptor family. Endocrine Rev $1991,12: 235-251$

41. Lebrun II, Ali S, Goffin V, Ullrich A, Kelly PA: A

- single phosphotyrosine residue of the prolactin receptor is responsible for activation of gene transcription. Proc Natl Acad Sci USA 1995, 92:4031-4035.

The analysis of mutated forms of the prolactin receptor yields important insights into the molecular details of Jak/Stat pathways. Mutant variants of the prolactin receptor were derived in which the intracellular domain was altered. Regions comprising tyrosine residues were deleted or changes from tyrosine residues to phenylalanine residues were introduced. The functional analysis of these variant receptors showed that a single tyrosine at position 580 , close to the carboxyl terminus, is necessary for the induction of prolactin-responsive gene expression.

42. Schmitt-Ney M, Doppler W, Ball RK, Groner B: Beta-casein gene promoter activity is regulated by the hormone-mediated relief of transcriptional repression and a mammary-gland-specific nuclear factor. Mol Cell Biol 1991, 11:3745-3755

43. Burdon TG, Demmer J, Clark AJ, Watson Cl: The mammary factor MPBF is a prolactin-induced transcriptional regulator which binds to SIAI factor recognition sites. FEBS Lett 1994 , 350:177-182.

44. Wakao $H$, Schmitt-Ney $M$, Groner B: Mammary specific nuclear factor is present in lactating reodent and bovine mammary tissue and composed of a single polypeptide of 89 kDa. I Biol Chem 1992, 267:16365-16370.

45. Wakao H, Gouilleux F, Groner B: Mammary gland factor - (MCF) is a novel member of the cytokine regulated transcription factor gene family and confers the prolactin response. $E M B O / 1994,13: 2182-2191$.

Describes the purification and molecular cloning of MGF/Stat5, which required the mammary glands of five lactating sheep. The transfection of an expression vector of MGF/Stat5 and the prolactin receptor, together with a $\beta$-casein promoter luciferase construct, and prolactin-dependent transactivation of the reporter gene is described. This was the first formal demonstration of the mechanism of prolactin-mediated transcriptional regulalion llirough MGF/Stat5.

46. Hou J, Schindler U, Henzel WJ, Wong SC, McKnight SL: Identification and purification of human Stat proteins activated in response to interleukin-2. Immunity 1995, 2:321-329.

47. Mui A, Wakao H, O'Farrell AM, Harada N, Miyajima A: Interleukin 3, granulocyte macrophage colony stimulating factor and interleukin 5 transduce signals through two Stat5 homologues. $E M B O / 1995,14: 1166-1175$.

48. Liu X, Gouilleux F, Groner B, Hennighausen L: Cloning and - expression of Stat5 and a novel homologue (Stat5b) involved in prolactin signal transduction in mouse mammary tissue. ProC Natl Acad Sci USA 1995, 92:in press.

Shows that isoforms of MGF/Stat5 are present in the mammary cells of mice. Their functional significance is not yet known.

49. Gouilleux F, Wakao $H$, Mundt $M$, Groner B: Prolactin induces -• phosphorylation of Tyr694 of Stat5 (MGF), a prerequisite for DNA binding and induction of transcription. $E M B O / 1994$, 13:4361-4369.

This important paper shows that tyrosine phosphorylation of MGF/Stat 5 occurs upon prolactin receptor activation and converts the latent molecule into a DNA-binding form. 
50. Happ B, Groner B: The activated mammary gland specific nuclear factor (MGF) enhances in vitro transcription of the beta-casein gene promoter. I Steroid Biochem Mol Biol 1993, 47:21-30.

51. Standke GJ, Meier VS, Groner B: Mammary gland factor activated by prolactin on mammary epithelial cells and acute-phase response factor activated by interleukin- 6 in liver cells share DNA binding and transactivation potential. $\mathrm{MO}$ Endocrinol 1994, 8:469-477.

52. Welte T, Garimorth K, Philipp S, Doppler W: Prolactin-dependent activation of a tyrosine phosphorylated DNA binding factor in mouse mammary epithelial cells. Mol Endocrinol $1994,8: 1091-1102$.

53. Marte BM, Meyer T, Stabel S, Standke G), Jaken S, Fabbro D, Hynes NE: Protein kinase $\mathbf{C}$ and mammary cell differentiation: involvement of protein kinase $\mathrm{C}$ alpha in the induction of beta-casein expression. Cell Growth Differ 1994, 5:239-247.

54. Happ B, Hynes NE, Groner B: Ha-ras and v-raf oncogenes, but not int-2 and c-myc, interfere with the lactogenic hormone dependent activation of the mammary gland specific transcription factor. Cell Growth Differ 1993, 4:9-15.

55. Schmitt-Ney M, Happ B, Ball R, Groner B: Developmental and environmental regulation of a mammary gland specific nuclear factor essential for transcription of the gene encoding betacasein. Proc Natl Acad Sci USA 1992, 89:3130-3134.

56. Schmitt-Ney $M$, Happ B, Hofer $P$, Hynes NE, Groner $B$ : Mammary gland specific nuclear factor activity is positively regulated by lactogenic hormones and negatively by milk stasis. Mol Endocrinol 1992, 6:1988-1997.

57. Kazansky A, Raught B, Lindsey SM, Wang $Y$, Rosen JM: Regulation of MGF-Stat5a during mammary gland development. Mol Endocrinol 1995, 9:in press.

58. Wood TI, Sliva D, Lobie PE, Pircher TJ, Gouilleux F, Wakao $H$, Gustafsson JA, Groner B, Norstedt G, Haldosen LA: Mediation of growth hormone-dependent transcriptional activation by mammary gland factor/Stat 5. J Biol Chem 1995 , 270:9448-9453.

59. Gouilleux F, Pallard C, Dusanter-Fourt I, Wakao H, Haldosen LA, Norstedt G, Levy D, Groner B: Prolactin, growth hormone, erythropoietin and granulocyte-macrophage colony stimulating factor induce MGF-Stat5 DNA binding activity. EMBO / 1995, 14:2005-2013.

60. Gobert S, Chretien S, Gouilleux F, Muller O, Pallard C, Dusanter-Fourt I, Groner B, Lacombe C, Gisselbrecht S, Mayeux $\mathrm{P}$ : Identification of tyrosine residues within the intracellular domain of the erythropoietin receptor crucial for Stat5 activation. $E M B O / 1995, \mathbf{1 4}$ : in press.

61. Fuji $H$, Nakagawa $Y$, Schindler $U$, Kawahara $A$, Mori $H$ Gouilleux F, Groner B, Ihlr JN, Minami Y, Miyazaki T, Taniguchi T: Activation of Stat5 by interleukin 2 requires a carboxyl terminal region of the interleukin 2 receptor beta chain but is not essential for proliferative signal transmission. Proc Natl Acad Sci USA 1995, 92:5482-5486.

62. Wakao $H$, Harada $N$, Kitamura $T$, Mui A Miyajima $A$ Interleukin 2 and erythropoietin activate Stat5/MGF via distinct pathways. $E M B O / 1995, \mathbf{1 4}: 2527-2535$
63. Gouilleux F, Moritz D, Humar M, Moriggl R, Berchtold $S$, Groner $B$ : Prolactin and interleukin 2 receptors in $T$ lymphocytes signal through a MGF Stat5 like transcription factor. Endocrinology 1995, in press.

64. Azam $M$, Bromage $H E$, Kreider $B L$, Xia $M$, Quelle $F$, Basu $R$, Saris $C$, Tempst $P$, thle JN, Schindler $C$ : Interleukin 3 signals through multiple isoforms of Stat5. EMBO / 1995, 14:1402-1411.

65. Pallard C, Gouilleux F, Charon M, Groner B, Gisselbrecht S, Dusanter-Fourt I: Interleukin 3, erythropoietin and prolactin activate a Stat5 like factor in lymphoid cells. / Biol Chem 1995, 270:in press.

66. Barahmand-pour F, Meinke A, Eilers A, Gouilleux F, Groner B, Decker T: Colony stimulating factors and interferon gamma activate a protein related to MGF/Stat5 to cause formation of the differentiation induced factor in myeloid cells. FEBS Lett 1995, 360:29-33.

67. Pallard C, Gouilleux F, Benit L, Cocault L, Souyri M, Levy D, Croner B, Gisselbrecht S, Dusanter-Fourt I: Thrombopoietin activates a Stat5 like factor in hematopoietic cells. $E M B O$ $1995,14: 2847-2856$

68. Ruff-Jamison S, Chen K, Cohen S: Epidermal growth factor induces the tyrosine phoshorylation and nuclear translocation of Stat 5 in mouse liver. Proc Natl Acad Sci USA 1995, 92:4215-4218

69. Darnell JE, Kerr IM, Stark GR: Jak-Stat pathways and - transcriptional activation in response to interferons and other extracellular signaling proteins. Science 1994, 264:1415-1421. See annotation $\left[70^{\circ} 1\right.$

70. Taniguchi $\mathrm{T}$ : Cytokine signaling through non-receptor protein - tyrosine kinases. Science 1995, 268:251-255.

This article and $\left[69^{\circ}\right]$ summarize the current thinking concerning cytokine action and transcriptional regulation. Darnell et al. $\left[69^{\bullet}\right]$ review the discoveries leading to interferon-responsive genes, the transcription factors binding to their promoters, and the cloning of the first Stat factors. Somatic cell genetics allowed the connection to be made between the Jak kinases and the mechanism of interferon action. Taniguchi $\left[70^{\bullet}\right]$ emphasizes the role of the intracellular domains of cytokine receptors as binding sites for non-receptor protein tyrosine kinases and as docking sites for $\mathrm{SH} 2$ domain containing proteins.

71. Luo $H$, Hanratty WP, Dearolf CR: An amino acid substitution in the Drosophila hop tum-I Jak kinase causes leukemia like hematopoietic defects. $E M B O$ / 1995, 14:1412-1420.

72. Harrison DA, Binari $R$, Nahreini TS, Gilman $M$, Perrimon $\mathrm{N}$ : Activation of a Drosophila Janus kinase (Jak) causes hematopoietic neoplasias and developmental defects. $E M B O$ J 1995, 14:2857-2865.

73. Watson C], Miller WR: Elevated levels of members of the STAT - family of transcription factors in breast carcinoma nuclear extracts. Br / Cancer 1995, 71:840-844.

This paper shows that MGF/Stat5 might be deregulated in breast cancer cells and contribute to cellular transformation.

B Groner and F Gouilleux, Institute for Experimental Cancer Research, Breisacher Straße 117, 1)-79106 Freiburg, Germany. 